\title{
Cassava Climate-Smart Agriculture Practices at Yen Binh District, Yen Bai Province, Vietnam
}

\author{
Duong Van Son \\ The Thai Nguyen University of Agriculture and Forestry (TUAF), Thai Nguyen province, Vietnam
}

\begin{abstract}
Cassava is an important cash crop, contributing to famer's income at the research site of Yen Binh district, Yen Bai province, where cassava is more important than rice, field crops have no production competition and forestry production is dominant based on diversified topography and steep lands. In that condition, it is obvious that indigenous knowledge in cassava production and practice plays an important role in the development of a sustainable and adaptive agriculture.

Local farmer practice in cassava intercropping with forest trees such as acacia and eucalyptus under agroforestry system seems to be as an appropriate choice for the site, is climate-smart agriculture (CSA) practices and technologies, indicating a typical example on CSA on cassava practice as CSA practices and technologies in small-scale farming. The common rotation in the agro-forestry system comprises 3 periods: cassava monoculture in 1-3 years, cassava intercropping with acacia or eucalyptus in 1-2 years, and acacia or eucalyptus (as mono-tree) in 4-6 years. Under the agro-forestry system, forest trees (such as acacia, eucalyptus) and cassava are good friends, their relationship seems very good and the farming system is sustainable.

It would be nice if we have more CSA options to enhance adaptive capacity among local farmers and stakeholders at the mentioned research site. It is interesting if we could have interventions on cassava technologies such as varietal introduction, soil fertility management, no or minimum tillage with hedgerows or mulch application and other cultivation practices on slopping lands.
\end{abstract}

Keywords: Cassava cultivation; Cassava intercropping; Climate smart agriculture

\section{INTRODUCTION}

Cassava, an annual crop, is considered as a highly resilient crop under climate change. The crop can be able to grow not only under good climate condition, but also under severe climate condition such as high temperature, hot condition or drought. Cassava can grow under drought and poor soil and still get a harvest, but maize is contrary with no harvest. Resilience is the capacity that ensures adverse stressors and shocks do not have long lasting adverse development consequences. Resilience relates to sustainable development and climate change (FAO, 2013) [3].

According to Julian F. Gonsalves (2014) [2], resilience is about capacity that prevents individuals, households and communities from falling below a normatively defined level for a given development outcome. Therefore, managing for resilience is an essential component of sustainable development. There is a relationship between resilience and climate-smart agriculture (CSA). CSA approach is proposed as a solution to transform and reorient agricultural systems, to ensure food security under the new realities of climate change (Dindo, 2014) [1]. CSA aims to sustainably increase productivity, adapt and build resilience to climate change at all levels - from the farm to national governments, and reduce or remove greenhouse gas emissions where possible. The CSA is composed of three main pillars: (1) sustainably increasing agricultural productivity and incomes; (2) adapting and building resilience to climate change; and (3) reducing and/or removing greenhouse gases emissions, where possible (FAO, 2013) [3].

Cassava is an important cash crop, contributing famer's income at the research site, a Root-TuberBananas CRP Post-harvest project (called shortly as RTB project). The RTB project works on livestock feeding with cassava starch processing residues and crop management to increase cassava production at communes of Vinh Kien and Phuc An (Yen Binh district, Yen Bai province, Northern Vietnam). The crop is an economically important crop for local smallholder farmers. Cassava farmers there are selling fresh roots to not only small-scale wet starch processors based at the communes, but 
also for Yen Binh dried starch factory located on Vu Linh commune nearby. It looks that the research site has disadvantages in agricultural production, due to almost agricultural lands are now under the Thac Ba lake, a hydro-power reservoir constructed in 70-year of last century. The total natural lands of research site are 5,300 ha, but agricultural land is small, only 760 ha, occupy $14.3 \%$. Of which, cassava area is 400 ha, rice area is 305 ha, maize area is 140 ha. Forestry lands are 3,254 ha, occupy $61.4 \%$ of the total natural lands, lake area within research site is 1,332 ha. The research site comprises 2,220 households with 9,200 residents, including four ethnic groups such as Kinh, Cao Lan, Dao and Thai.

The paper describes some cassava cultivation practices as an indigenous knowledge of local farmers. It looks like as CSA practices from local farmers in small-scale farming. It would be nice if we have more CSA options to enhance adaptive capacity among local farmers and stakeholders.

\section{MethodS}

The research site covers the two RTB project communes namely Phuc An and Vinh Kien (Yen Binh district, Yen Bai province, Northern Vietnam).

The main contents of the research are: (1) Cassava in crops livelihood of local farmers, and (2) Cassava climate smart agriculture (CSA) practices, including intercropping, soil fertility management and erosion control.

Key methods were applied for the research including field observation and surveys-questionnaires with household survey. There are 96 questionnaires were conducted at two mentioned RTB communes by a survey team from the Thai Nguyen University of Agriculture and Forestry (TUAF).

Data was analyzed by Excel-PivotTable. Statistical analysis of the sample is used by some common statistical quantities such as Standard Deviation (Std Dev or SD), Mean, Standard Error (SE), Coefficient of Variation (CV\%).

\section{ReSUlts AND DiscusSions}

\subsection{Cassava in Crops Livelihoods of Local Farmers}

Table1. Crops Households Growing, Area and Income by Wealth Ranking

\begin{tabular}{|c|c|c|c|c|c|c|c|}
\hline \multirow{2}{*}{ Crops } & \multirow{2}{*}{ Norm } & \multicolumn{3}{|c|}{ Wealth ranking } & \multirow{2}{*}{ Mean } & \multirow{2}{*}{ SD } & \multirow{2}{*}{ SE } \\
\hline & & Non-poor & Less poor & Poorest & & & \\
\hline \multirow{3}{*}{ Cassava } & $\%$ HHs growing & 80.2 & 7.3 & 4.2 & & & \\
\hline & Area $\left(\mathrm{m}^{2}\right)$ & 8,605 & 7,817 & 4,698 & 8,365 & 13,501 & 1,439 \\
\hline & $\%$ income & 50.4 & 53.7 & 67.8 & 51.5 & 26.4 & 2.8 \\
\hline \multirow{3}{*}{ Rice } & $\%$ HHs growing & 68.8 & 6.3 & 4.2 & & & \\
\hline & Area $\left(\mathrm{m}^{2}\right)$ & 1,986 & 1,147 & 955 & 1,866 & 1,282 & 147 \\
\hline & $\%$ income & 29.9 & 23.8 & 34 & 29.6 & 16.6 & 1.9 \\
\hline \multirow{3}{*}{ Maize } & $\%$ HHs growing & 22.9 & 1.0 & 0.0 & & & \\
\hline & Area $\left(\mathrm{m}^{2}\right)$ & 586 & 1,000 & 0.0 & 604 & 483 & 101 \\
\hline & $\%$ income & 11.2 & 10 & 0.0 & 11.2 & 9.6 & 2 \\
\hline \multirow{3}{*}{ Eucalyptus } & $\%$ HHs growing & 20.1 & 4.2 & 0.0 & & & \\
\hline & Area $\left(\mathrm{m}^{2}\right)$ & 8,144 & 21,000 & 0.0 & 9,369 & 6,834 & 1,395 \\
\hline & $\%$ income & 36.2 & 52.5 & 0.0 & 37.8 & 25.8 & 5.3 \\
\hline \multirow{3}{*}{ Acacia } & $\%$ HHs growing & 20.1 & 2.1 & 0.0 & & & \\
\hline & Area $\left(\mathrm{m}^{2}\right)$ & 15,438 & 8,000 & 0.0 & 15,084 & 11,468 & 2,445 \\
\hline & $\%$ income & 46.1 & 11 & 0.0 & 44.4 & 25.2 & 5.4 \\
\hline \multirow{3}{*}{ Sweetpotato } & $\%$ HHs growing & 10.4 & 2.1 & 0.0 & & & \\
\hline & Area $\left(\mathrm{m}^{2}\right)$ & 424 & 150 & 0.0 & 399 & 252 & 76 \\
\hline & $\%$ income & 21.7 & 51.5 & 0.0 & 26.7 & 35.7 & 10.3 \\
\hline \multirow{3}{*}{ Peanuts } & $\%$ HHs growing & 6.3 & 1.0 & 0.0 & & & \\
\hline & Area $\left(\mathrm{m}^{2}\right)$ & 760 & 3,000 & 0.0 & 1,080 & 1,327 & 502 \\
\hline & $\%$ income & 11.7 & 50 & 0.0 & 17.1 & 18 & 6.8 \\
\hline \multirow{3}{*}{ Tea } & $\%$ HHs growing & 6.3 & 1.0 & 0.0 & & & \\
\hline & Area $\left(\mathrm{m}^{2}\right)$ & 1,340 & 10,000 & 0.0 & 2,577 & 3,385 & 1,279 \\
\hline & $\%$ income & 17.4 & 0 & 0.0 & 17.4 & 12.8 & 5.7 \\
\hline \multirow{3}{*}{ Forage } & $\%$ HHs growing & 7.3 & 2.1 & 0.0 & & & \\
\hline & Area $\left(\mathrm{m}^{2}\right)$ & 394 & 570 & 0.0 & 433 & 264 & 88 \\
\hline & $\%$ income & 11.3 & 0 & 0.0 & 11.3 & 6.3 & 3.1 \\
\hline
\end{tabular}


Surveyed result shown that for food crops, cassava is more important than rice. Among 96 surveyed households total, there are $91.7 \%$ households growing cassava averagely 8,365 square meters per households who growing cassava with high SD (13,501 square meters) and high SE (1,439 square meters). While for rice there are $79.3 \%$ surveyed households growing rice with averagely 1,866 square meters per households who growing rice. For maize, only $23.9 \%$ surveyed households growing maize with averagely 604 square meters per households among those households growing maize. Regarding income from mentioned food crops, obviously cassava is highest (51.5\%), next is rice (29.6\%), maize (11.2\%). It means that the communes have no advantage for agricultural production, especially rice production. In addition, there are $12.5 \%$ of local farmers growing sweet potato, $7.3 \%$ growing peanuts and $9.4 \%$ of surveyed households growing forage as animal feeds.

For the long-term crops and trees, two forest trees have been grown by local farmers are eucalyptus and acacia. Of which, there are $24.4 \%$ of surveyed households planting eucalyptus with area of 9,369 square meters, contributing household income of $37.7 \%$. While there are $22.2 \%$ of surveyed households planting acacia with area of 15,084 square meters, contributing household income of $44.4 \%$, higher than eucalyptus. There are $7.3 \%$ of surveyed households growing tea with planting area is 2,577 square meters (Table 1 ).

Generally, with diverse topography and steep mountains in domination, explaining the advantage for forest trees such as eucalyptus, acacia... While crops livelihood for local farmers in research site looks poor, indicating the competition for production of field crops such as rice, maize, peanuts, soybean... is not very high. Cassava seems to be a best choice of all local ethnic groups for their production in the uplands, slopping lands.

Table2. Households Growing Cassava in Slopping Lands

\begin{tabular}{|l|l|l|l|l|l|l|}
\hline \multirow{2}{*}{ Ethnicity } & Yes & No & \multicolumn{2}{l|}{ Total } \\
\cline { 2 - 7 } & $\mathbf{n}$ & $\mathbf{\%}$ & $\mathbf{n}$ & $\mathbf{\%}$ & $\mathbf{n}$ & $\mathbf{\%}$ \\
\hline Kinh & 38 & $42.22 \%$ & 2 & $2.22 \%$ & 40 & $44.44 \%$ \\
\hline Cao lan & 27 & $30.00 \%$ & 5 & $5.56 \%$ & 32 & $35.56 \%$ \\
\hline Dao & 15 & $16.67 \%$ & 2 & $2.22 \%$ & 17 & $18.89 \%$ \\
\hline Thái & 1 & $1.11 \%$ & & $0.00 \%$ & 1 & $1.11 \%$ \\
\hline Total & $\mathbf{8 1}$ & $\mathbf{9 0 . 0 0 \%}$ & $\mathbf{9}$ & $\mathbf{1 0 . 0 0 \%}$ & $\mathbf{9 0}$ & $\mathbf{1 0 0 . 0 0 \%}$ \\
\hline
\end{tabular}

Actually, cassava was grown by all ethnic groups, including Kinh, Cao Lan, Dao and Thai living at the research site. There are $90 \%$ of cassava growers ( 81 households) planting the crop at the slopping lands with slop level is 40-45 degrees of steepest field (Table 2). Therefore, erosion is a big problem for cassava production, creating soil loss and soil fertile degression. The question raised here is how to manage and control slopping lands, how cassava planting practices are and how are agro-forestry systems at such sites, where slopping lands are dominant and cassava is farmer's alternatives.

\subsection{Cassava Climate-Smart Agriculture Practices at the Research Site}

Cassava is an annual crop with 8-10 months from planting to harvesting. Farmers there can be able to grow cassava at the fields where trees (e.g. acacia, eucalyptus) are also grown, indicating their local and indigenous adaptation practices. Table 3 shown that there are $65.43 \%$ of cassava farmers planting cassava in the fields where the forest trees are also grown.

Regarding erosion management, it is said that intercropping is one of the best way for erosion control, mostly to cover the surface of lands when the crops are still small. This shows that farmers can harvest a second crop (for increased income or food security) that protects the soil from raindrop impact before the cassava canopy closure - to control erosion, reduces weed completion, and possibly adds organic nitrogen to the soil to improve productivity and sustainability.

Table3. Households Growing Cassava at Fields where Trees are also Grown

\begin{tabular}{|l|l|l|l|l|l|l|}
\hline \multirow{2}{*}{ Ethnicity } & Yes & No & \multicolumn{2}{l|}{ Total } \\
\cline { 2 - 7 } & $\mathbf{n}$ & $\mathbf{\%}$ & $\mathbf{n}$ & $\mathbf{\%}$ & $\mathbf{n}$ & $\mathbf{\%}$ \\
\hline Kinh & 22 & $27.16 \%$ & 12 & $14.81 \%$ & 34 & $41.98 \%$ \\
\hline Cao lan & 20 & $24.69 \%$ & 12 & $14.81 \%$ & 32 & $39.51 \%$ \\
\hline Dao & 11 & $13.58 \%$ & 4 & $4.94 \%$ & 15 & $18.52 \%$ \\
\hline Total & $\mathbf{5 3}$ & $\mathbf{6 5 . 4 3 \%}$ & $\mathbf{2 8}$ & $\mathbf{3 4 . 5 7 \%}$ & $\mathbf{8 1}$ & $\mathbf{1 0 0 . 0 0 \%}$ \\
\hline
\end{tabular}

Actually, local farmers can be able to intercrop cassava with various field crops and forest trees, including annual crops and long-term trees as forest trees. Table 4 shown that, local farmers can intercrop cassava with eucalyptus, acacia, tea, black bean, peanuts, maize, forage and mung-bean. The 


\section{Duong Van Son}

two-top ranking is long-term trees such as eucalyptus and acacia with $37.65 \%$ and $18.82 \%$ households planting, respectively. The reason for the rank and choice is that mentioned agro-forestry systems, including forest trees (e.g. eucalyptus, acacia, tea) and cassava can be to adapt for soil and lands, to get high and sustainable income. Cassava can provide cash income in short-term and mentioned forest trees can provide income in long-term, means that all mentioned forest trees and cassava are friends, their relationship seems very good and the farming system is sustainable. While eucalyptus can be able to get second generation after first harvest (Eucalyptus can be able to have 2 or more harvest from seedling up to soil management), but acacia is contrary and that tree only have one harvest from seedling, explaining that first ranking is eucalyptus and acacia is second one (Table 4).

Table4. Intercrops Ranking with Cassava

\begin{tabular}{|l|l|l|l|l|}
\hline Intercrops & $\begin{array}{l}\text { Households } \\
\text { growing }\end{array}$ & $\begin{array}{l}\text { \% Households } \\
\text { growing }\end{array}$ & Ranking & Reason \\
\hline Eucalyptus & 32 & $37.65 \%$ & 1.2 & Appropriate soil, high and sustainable income \\
\hline Acacia & 16 & $18.82 \%$ & 1.0 & Appropriate soil, high and sustainable income \\
\hline Black bean & 12 & $14.12 \%$ & 1.5 & Soil improvement, high income \\
\hline Peanuts & 11 & $12.94 \%$ & 1.2 & Soil improvement, high income \\
\hline Maize & 9 & $10.59 \%$ & 2.2 & Maize for feeding \\
\hline Tea & 2 & $2.35 \%$ & 1.0 & High income \\
\hline Forage & 2 & $2.35 \%$ & 3.0 & Soil erosion control, forage for cattle and buffalo \\
\hline Mung-bean & 1 & $1.18 \%$ & 1.0 & Soil improvement, high income \\
\hline Total/mean & $\mathbf{8 5}$ & $\mathbf{1 0 0 . 0 0 \%}$ & $\mathbf{1 . 4}$ & \\
\hline
\end{tabular}

Regarding the field crops, local farmers said that, intercropping cassava with legume (mung-bean, peanuts and black bean) could get high income and soil improvement. For maize can be feed for animal feeding not only the seeds, but also fold (stems and leaves). Intercropping cassava with forage can get forage for cattle and buffalo feeding, and also for soil erosion control (Table 4).

Percentage of households growing various trees and field crops in Table 4, mostly attracting on forest trees, indicates that while field crops are not high competition for production, mentioned long-term trees such as eucalyptus and acacia are the best choice for intercropping under available cultivation systems, explaining that the high potentials for agro-forestry production locally.

Table5. Number of Year Forest Trees are Grown Each Rotation, Cassava Grown with/without Tea

\begin{tabular}{|l|c|c|c|}
\hline Forestry & $\begin{array}{c}\text { Number of years, trees are } \\
\text { grown each rotation }\end{array}$ & $\begin{array}{c}\text { Number of year cassava } \\
\text { grown with forest trees }\end{array}$ & $\begin{array}{c}\text { Number of year cassava grown } \\
\text { without forest trees }\end{array}$ \\
\hline Eucalyptus & 5.0 & 1.4 & 1.6 \\
\hline Acacia & 7.0 & 1.2 & 2.4 \\
\hline Tea & - & 1.0 & - \\
\hline Mean & 5.7 & 1.3 & 1.9 \\
\hline SD & 2.0 & 0.7 & 1.3 \\
\hline SE & 0.2 & 0.1 & 0.3 \\
\hline
\end{tabular}

Regarding mentioned long-term trees, all 3 mentioned trees are cash trees for local farmers income at the research site. In agro-forestry system, forest trees are grown in each rotation with duration from planting to harvest is 5-7 years, up to trees (with eucalyptus is 5 years and acacia is 7 years). Of which, number of year cassava intercrops with forest trees varies from 1-2 years (with eucalyptus is averagely 1.4 years, acacia is averagely 1.2 years). After harvesting mentioned forest trees, cassava is grown as mono cropping (without forest trees) in 1-3 years, depending on land availability, family investment budget and trees. The survey data shown that, with eucalyptus is averagely 1.6 years, and acacia is 2.4 years (Table 5). In sum, common rotation in the agro-forestry system here includes 3 periods: (1) Cassava mono cropping in 1-3 years, (2) Cassava intercropping with acacia or eucalyptus in 1-2 years, and (3) Acacia or eucalyptus (as mono-tree) in 4-6 years. In other hand, one rotation of forest trees includes cassava intercropping and forest tree monoculture or mono-trees. Other side, one rotation of cassava includes cassava monoculture and cassava intercropping with forest trees.

Table6. Cassava Fertilizer Application in First Year Intercropped with Forest Trees

\begin{tabular}{|l|l|l|l|}
\hline $\begin{array}{l}\text { Cassava fertilizer application in first } \\
\text { year intercropped with trees }\end{array}$ & No.of households & Percentage & Amount application (kg/ha) \\
\hline Yes & 55 & $91.67 \%$ & 308 \\
\hline No & 5 & $8.33 \%$ & \\
\hline Total & $\mathbf{6 0}$ & $\mathbf{1 0 0 . 0 0 \%}$ & $\mathbf{3 0 8}$ \\
\hline
\end{tabular}


Accompanying with intercropping under agro-forestry system, local farmers did apply the NPK compost namely NPK Lam Thao (with NPK rate $=5: 10: 5$ ), made by a Lam Thao chemical fertilizer company located at Viet Tri city, Phu Tho province, very closed Yen Bai province for cassava not only in first year intercropped with forest trees, but also for second years intercropped with mentioned trees. Surveyed data shown that, there are $91.67 \%$ of households who did intercrop cassava with trees in first year, applying the NPK Lam Thao with amount of $308 \mathrm{~kg}$ per ha (Table 7). Surveyed data also shown that, there are $34.69 \%$ households who did intercrop cassava with trees in second year, applying the NPK Lam Thao with amount of $384 \mathrm{~kg}$ per ha (Table 8). It implies that cassava soil fertilizer management by applying the NPK compost is good farmer practice ensuring sustainable production. It is interesting that local farmers can be able to apply that NPK compost instead of single fertilizer like Nitrogen, Potassium or Phosphate for labor save and efficient use, even although the NPK ratio of the Lam Thao compost currently still do not meet the nutrient requirement of cassava plant (due to low rate of $\mathrm{K}$ content). Therefore, the meeting between the chemical fertilizer company and research team with the participation of the extension officers and other development organizations for discussion about cassava nutrient and NPK compost production with appropriate NPK ratio will be worthwhile.

Table7. Cassava Fertilizer Application in Second Year Intercropped with Forest Trees

\begin{tabular}{|l|l|l|l|}
\hline $\begin{array}{l}\text { Cassava fertilizer application in } \\
\text { second year intercropped with trees }\end{array}$ & N0.of households & Percentage & Amount application (kg/ha) \\
\hline Yes & 17 & $34.69 \%$ & 384 \\
\hline No & 32 & $65.31 \%$ & \\
\hline Total & $\mathbf{4 9}$ & $\mathbf{1 0 0 . 0 0 \%}$ & $\mathbf{3 8 4}$ \\
\hline
\end{tabular}

Interaction relationship between cassava and forest trees under agro-forestry system and rotation is an interesting issue for discussion. It looks that both cassava and mentioned forest tree are good friend under rotation and system, not only during intercropped time, but also during mono-cropping or mono-tree time. Surveyed result had shown that when intercropping cassava with forest trees, the forest trees grow better, no change and worse as farmer's answers are $56 \%, 24 \%$ and $20 \%$, respectively (Table 8).

Table8. How do Forest Trees Grow when Intercrops with Cassava

\begin{tabular}{|l|l|l|}
\hline How do forest trees grow when intercrop with cassava & N0.of households & Percentage \\
\hline Worse & 10 & $20.00 \%$ \\
\hline No change & 12 & $24.00 \%$ \\
\hline Better & 28 & $56.00 \%$ \\
\hline Total & $\mathbf{5 0}$ & $\mathbf{1 0 0 . 0 0 \%}$ \\
\hline
\end{tabular}

The intercropping cassava with forest trees could be attractive - if farmers consider that they have enough cassava to harvest to compensate for the extra labor. Table 9 shown that when intercropping cassava with forest trees, it increases labor amount for the whole intercropping season, including more land preparation, more planting time, more weeding, more harvesting, transportation and post-harvest with averagely additional 2.5 man-day per 1000 square meters for both male and female in the family, with female seems to be more labor days than male, indicating that intercropping cassava with forest trees also has an impact on each task during intercropping season of gender in the farmer's family.

Table9. Increased Labor Amount for Cassava Production due to Intercropping (Man-Day/1000 M²)

\begin{tabular}{|l|l|l|l|l|}
\hline Task & $\begin{array}{l}\text { Total additional labor-days per season for } \\
\text { intercropping }\end{array}$ & Male days & Female days \\
\hline Land preparation & 2.7 & 1.5 & 1.4 \\
\hline Planting & 2.4 & 1.0 & 1.6 \\
\hline Weeding & 2.4 & 1.0 & 1.7 \\
\hline Harvesting & 2.8 & 1.3 & 1.8 \\
\hline Transportation & 2.4 & 1.8 & 1.1 \\
\hline Post-harvest & 1.8 & 1.1 & 1.6 \\
\hline Mean & $\mathbf{2 . 5}$ & $\mathbf{1 . 3}$ & $\mathbf{1 . 6}$ \\
\hline SD & 1.1 & 0.7 & 0.8 \\
\hline SE & 0.1 & 0.1 & 0.1 \\
\hline
\end{tabular}


Note that, we did not include a mono-crop cassava, so we do not know how much cassava yield reduction there is from intercropping with forest trees. This could be a good discussion point. It is interesting that intercropping with forest trees did not decrease cassava yield in any case - in fact it greatly increased cassava yield in several cases, as farmers said during the surveys - and that the wider inter-row forest tree spacing had the highest cassava yields and the highest tree yields. In that case both cassava and forest trees are win-win situation.

\section{Conclusion}

Cassava is an important cash crop, contributing famer's income at the research site of Yen Binh district, Yen Bai province, where cassava is more important than rice, field crops have no production competition and forestry production is dominant due to diversified topography and steep lands. In that condition, it is obvious that indigenous knowledge in cassava production and practice plays an important role in the development of a sustainable and adaptive agriculture.

Local farmer practice in cassava intercropping with forest trees such as acacia and eucalyptus under agro-forestry system seems to be as an appropriate choice for the research site, is as climate-smart agriculture (CSA) practices, indicating a typical example on CSA on cassava practice as CSA practices in small-scale farming. The common rotation in the agro-forestry system comprises 3 periods: Cassava monoculture in 1-3 years, cassava intercropping with acacia or eucalyptus in 1-2 years, and acacia or eucalyptus (as mono-tree) in 4-6 years. It implies that one rotation of forest trees includes cassava intercropping and forest tree in monoculture or mono-trees. Other side, one rotation of cassava includes cassava monoculture and cassava intercropping with forest trees. Therefore, under the agro-forestry system, forest trees (acacia, eucalyptus) and cassava are good friends, their relationship seems to be very good and the farming system is sustainable.

It would be nice if we have more CSA options to enhance adaptive capacity among local farmers and stakeholders at the mentioned research site. It is interesting if we could have interventions on cassava technologies such as varietal introduction, soil fertility management, no or minimum tillage with hedgerows or mulch application and other cultivation practices and technologies on slopping lands. Integrated cassava CSA technologies and practices, including indigenous knowledge from local farmers and new technologies, will be necessary for sustainable production at the mentioned research site and other cassava areas in Northern Vietnam as well, where cassava planted at slopping lands.

\section{ACKNOWLEDGEMENTS}

The authors would like to thank the International Center for Tropical Agriculture (CIAT) and RTBCRP Post-harvest project for generous support that enabled this research.

\section{REFERENCES}

[1] Dindo M. Campilan, 2014. Social learning for climate-smart agriculture (CSA). CCAFS/CIAT, 2014.

[2] Julian F. Gonsalves, 2014. Arriving at the Need for Community-based Approach in climatesmart agriculture (CSA). CCAFS, 2014.

[3] FAO, 2013. Climate Smart Agriculture: A Resource book. 2013. 